INDEPENDENT JOURNAL OF MANAGEMENT \& PRODUCTION (IJM\&P)

http://www.ijmp.jor.br v. 11, n. 9, Special Edition (Baltic States), November 2020 ISSN: 2236-269X

DOI: 10.14807/ijmp.v11i9.1422

\title{
PRIORITY AREAS OF STRENGTHENING THE ECONOMIC SECURITY OF THE FOOD INDUSTRY
}

\author{
Kateryna Fen \\ Yuriy Fedkovych Chernivtsi National University, Ukraine \\ E-mail:fenkat4@gmail.com
}

Yevheniia Skljar

Yuriy Fedkovych Chernivtsi National University, Ukraine

E-mail: skljar.ewgeniya@gmail.com

Alla Chykurkova

State Agrarian and Engineering University in Podilya, Ukraine

E-mail: alladomanchuk@gmail.com

Nataliya Sokrovolska

Yuriy Fedkovych Chernivtsi National University, Ukraine

E-mail: n.sokrovolska@chnu.edu.ua

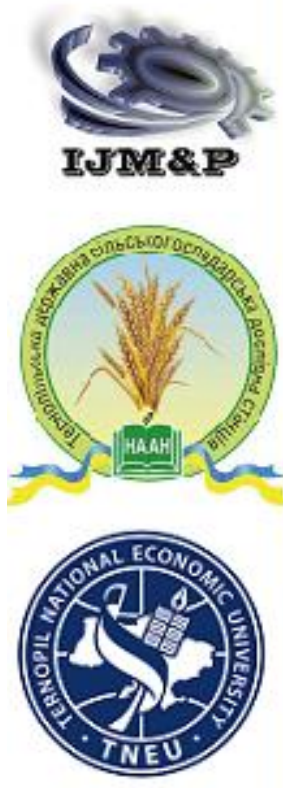

Kateryna Nakonechna National University of Life and Environmental Sciences of Ukraine, Ukraine E-mail: kln273125@gmail.com

Submission: $8 / 16 / 2020$

Revision: $8 / 31 / 2020$

Accept: $9 / 8 / 2020$

\section{ABSTRACT}

The current operating conditions of enterprises are due to a high degree of instability, which is due to the situation affected by the global economic crisis. This leads to a general decrease in the level of economic security of enterprises and, as a consequence, the ability to ensure their sustainable development. Insufficient elaboration of the problem of overcoming the low level of economic security of food industry enterprises of Ukraine and the need to further disclose a number of issues to determine the components of the economic security system and the mechanism of its strengthening determined the purpose and objectives of research. The purpose of the research is to outline the priority areas for strengthening the economic security of the food industry of Ukraine. In accordance with the outlined goal, the following complex scientific tasks were set and solved: the conceptual bases of the mechanism of formation and strengthening of economic security of enterprises, which ensures the implementation of the innovative strategy of their development, 
DOI: 10.14807/ijmp.v11i9.1422

were researched and substantiated; to make forecast calculations of indicators of the level of economic security in the conditions of its strengthening for the investigated enterprises of the branch; an assessment of the impact of various factors influencing the formation of economic security of food industry enterprises of Ukraine; substantiated components of the economic security management system of food industry enterprises, the functioning of which is ensured by the implementation of a set of strategies, supplemented by a strategy of positive image formation and analysis of the initial position of the enterprise, development and implementation of corrective measures based on effective management.

Keywords: Enterprise; Economic; Security; Food; Industry; Risks; Profitability; Image; Strategy

\section{INTRODUCTION}

Nowadays under market unsteadiness conditions, the successful development and functioning of any business entity depends heavily on a reliable, high-quality and sound economic security system for the enterprise. In the practice of conducting business of the national food industry enterprises, economic security measures are overwhelmingly unsystematic. In the conditions of uncertainty and instability of the environment, competition, economic fluctuations in the economy, overcoming the consequences of the global financial crisis for the successful and long-term functioning of the enterprise in the market becomes crucial to the formation and development of its economic security system. The process of strengthening the food industry economic security is complex, with a large number of various external and internal threats that impede its sustainability, stability and effective development.

Despite the large number of works and publications, the wideness and complexity of the problem require continued scientific research and further specification of the acquired knowledge. Insufficient elaboration of some items in within this problem and the need for further disclosure of a number of questions regarding the determination of the economic security system components and the mechanism of its strengthening at the food industry enterprises made the research relevant, determined the aim and tasks of the research.

The urgency of the economic security issue has become almost paramount now. The continued crisis in Ukraine, due to which there is a marked decline in the potential of most businesses, has negatively affected the level of security to both the state and society. National food companies are not able to handle the current situation on their own; they need the state support and the situation resolution. At present, the strategic task of the state, legislative and 
DOI: 10.14807/ijmp.v11i9.1422

executive power, local self-government, as one of the forming components of a socially oriented market economy, is to solve the problem of strengthening the economic security of the country and its population. The consequences of the global economic crisis create real threats to Ukraine national security, in particular its important component, such as the economic security.

Thus, the relevance of the study of strengthening the economic security of enterprises of such a strategically important industry as the food industry is crucial for national security of Ukraine and led to the formation of the purpose of research in the context of ensuring the implementation of the proposed measures.

\section{LITERATURE REVIEW}

Various aspects of economic security formation have been investigated by such scientists as: KOZACHENKO (2013), VASYLTSIV (2008), IHNASHKINA (2019), MASLAK (2013), HRYSHKO (2013), CHYKURKOVA (2016), SKLIAR (2012), ANISHCHENKO (2005), ILIENKO (2013), MISHCHENKO (2012), GORYACHEVA (2003), DONECZ (2008), PONOMAREV (1998), FRANCHUK (2009), MOJSEYENKO (2011), MARCHENKO (2011), VASHCHENKO (2011), ANDREYEVA (2011), MARTYUSHEVA (2008), BAZHENOVA (2018), PYRUMOV (1993), HAUSHOFER (2001), POLYARUSH (2011), YURCHENKO (2011), SYVOLAP (2014), FEN (2018), SAATI (1193).

Most scientists consider the essence of the ensuring economic security mechanism only through the composition of its components, without allocation to a separate category of the specified term. At the same time, the definition of "mechanism for ensuring the enterprise economic security" in the scientific literature is virtually undefined

So, GORYACHEVA (2003) defines the concept of "economic security mechanism" as the unity of the management process and the management system.

DONETS et al. (2011) believe that it is a set of tools, as well as a system of their use and control organization, which allow to achieve the highest level of the enterprise financial security.

PONOMAREV (1998) proposes to apply the notion as a set of managerial, economic, organizational, legal and motivational ways of harmonizing the interests of the enterprise with the interests of environmental subjects, whereby taking into account the peculiarities of the 
DOI: 10.14807/ijmp.v11i9.1422

enterprise activity provides them with a profit, where the value is sufficient, as at a minimum, for financial security purposes.

FRANCHUK (2009) believes that it is the systematic interaction of subjects and security forces and the systematic combination and application of common and special security functions, methods, means, forms and principles.

Some authors differentiate between the notion of "securement mechanism" and "management mechanism". Generally speaking, the mechanism is the coordination of the management system space and time, which leads to qualitative changes in the management entity by MOJSEYENKO et al. (2011).

The purpose of the "management mechanism" at the enterprise is to ensure economic security. That is, the result of management cannot be considered separately from the system of influence the subject on the object in order to create conditions for guaranteeing the protection against the danger by MARTYUSHEVA et al. (2008).

Therefore, the economic security of the enterprise can be considered as an internal state of the enterprise resources, which ensure their efficient use for stability of activity and progressive development, allows eliminating threats, to harmonize economic interests with values of the environment subjects. In this case, economic security should be studied through the prism of the enterprise internal properties to resist the economic threats.

The importance of investigation the peculiarities of the formation of enterprises economic security in the context of global globalization, first of all, is due to the slowdown in the development of food industry enterprises in the conditions of the e global financial recovery. Accordingly, it is necessary to carry out a system and structural analysis and to study useful world experience in ensuring the economic security of these enterprises in other developed countries. It is believed that the theoretical and applied principles elaboration of enterprise development, the formation of a favourable economic and legal environment for conducting business activities on innovative grounds will ensure the strengthening of the enterprises economic security.

At the same time, it is considered that the development of measures to ensure the direct economic security of the enterprise is a priority for countries that are changing the system of government due to the crisis in society. In prosperous countries, programmatic and targeted management in the processes of ensuring economic security is carried out, which foresees the 
DOI: 10.14807/ijmp.v11i9.1422

development of targeted strategic planning documents to strengthen enterprises, regions, and industries economic security.

Nowadays, in the context of the global economic crisis, new relationships are formed in the hierarchical decompostion of economic security, i.e. global, international, national, regional economic components of BAZHENOVA (2018).

Globalization is a phenomenon that has fully declared itself in the last third of the XX century, it has destroyed our ideas "about space and time, about the coordinate system according to which we have organized the reality" by BAZHENOVA (2018) and it was in the formation of global economic, financial, cultural, legal and political space. These elements of global space directly affect social practices, regardless of geographical location, culture, language, economy and finances of a country. Thus, their impact on political processes, both in individual countries and around the world, has to be taken into account.

It is legitimate to conclude that modern geopolitics will only retain its scientific status if it can reach the level of analysis of the laws that determine the interaction of social space and politics, the formation of basic principles and laws of policy making, designed to ensure control over social space.

We can agree with the view of the researcher PYRUMOV (1993), who draws attention to the fact that in view of the fundamental changes taking place in the world today, it is necessary to increase attention to the conceptual provisions of geopolitics. At the same time, the author defines the "underdevelopment" of the geopolitical research methodology. $\mathrm{He}$ suggests defining geopolitics as a science that studies the development processes and principles of the state, regions and the world as a whole, due to the systemic influence of geographical, political, economic, military, environmental and other factors.

The essence of the social space security characteristic is revealed, defining it as the most important factor of the modern world politics. In this sense, geopolitics is more likely to claim the status of a political science methodology.

Apparently, under the conditions of a certain methodological vacuum, not only in Ukraine but also in developed countries, including the USA, which was caused by radical transformations after the collapse of the communist bloc, similar methodological claims on the part of geopolitics are quite justified. In any case, resources and space, as the object of the political aspirations of the state in contemporary international relations, are more material, tangible and objective element for analysis than universal human values and human rights. 
DOI: 10.14807/ijmp.v11i9.1422

The geopolitics object is rightly regarded as a policy of states in its connection with social space, and then logically solves the question of this space structuring. It is obvious that purely geographical elements form only part of the social space, which, together with them, includes other forms, including political, economic, cultural, financial, information, linguistic and other space. The nature of their influence on the process of policy formation and implementation of both individual states and world policy in general will be the main content of modern geopolitics, which is carried out in the absence of free resources and spaces in the world. They are divided, assigned to specific countries and people in today world order their mere appropriation using military force is unlikely.

The classic of German geopolitics HAUSHOFER (2001) states that "only in our time, when even the ice space of the polar regions is predominantly politically divided, there is limited freedom of action for such great deeds in extending the living space of mankind". That is why other forms of expansion are taking effect.

It will be impossible to ensure the economic security of business entities without the effective cooperation of private security forces with national law enforcement agencies on the one hand and without international coordination of efforts with the security forces of foreign entities on the other. In such circumstances, the question of the effective functioning of the security forces of business entities acquires a level of national interest, especially in terms of national security. That is, ensuring the economic security of business entities in the context of globalization is a priority not only in one area of economic activity, but also has a leading role in protecting the economic interests of the country. An important factor here will be the state regulation of all parties relationship involved in ensuring the security of the national economy through the formation of relevant legal rules (POLYARUSH et.al., 2011).

Globalization processes oblige the economic security of business entities to build their activities with a view to prevent threats, that is, the functioning of their economic security systems have to be based on a combination of protection measures and counteraction to threats, extending such measures to the entire structure of business entities institutions.

As the foreign experience shows, such approaches should anticipate the joint activities of the security forces of both national and foreign entities throughout the course of their relations.

While ensuring the economic security of business entities, it may be necessary to take into account changes in the social situation. Increasing international labour migration and 
DOI: 10.14807/ijmp.v11i9.1422

reducing the number of employed people can lead to an increase in criminal influence on business activity, which also requires economic security for businesses in a globalized environment. It will be necessary to pay attention not only and not so much to creation of the enterprises and banks protection systems, as for the work with their staff, clients, to strengthen propaganda of a reliable and strong system of financial and material resources protection capable to resist any criminal encroachment by ILYENKO (2013).

The food industry economic security takes great socio-economic importance not only for Chernivtsi region in particular but also for Ukraine in general. Food and beverage production is not only the final link in food production, but also an integrator of the effective functioning of the entire food complex. From its development level, functioning stability depends on the state of the economy in the region, the internal and external markets development, the living standard of the population.

The purpose of the research is to outline the priority areas for strengthening the economic security of the food industry of Ukraine. In accordance with the outlined goal, the following complex scientific tasks were set and solved: the conceptual bases of the mechanism of formation and strengthening of economic security of enterprises, which ensures the implementation of the innovative strategy of their development, were researched and substantiated; to make forecast calculations of indicators of the level of economic security in the conditions of its strengthening for the investigated enterprises of the branch; an assessment of the impact of various factors influencing the formation of economic security of food industry enterprises of Ukraine; substantiated components of the economic security management system of food industry enterprises, the functioning of which is ensured by the implementation of a set of strategies, supplemented by a strategy of positive image formation and analysis of the initial position of the enterprise, development and implementation of corrective measures based on effective management.

\section{METHODOLOGY}

Theoretical and methodological principles of the study are based on systematic analysis - to detail and divide economic security into separate important components; synthesis - to summarize various aspects of the formation and strengthening of economic security of food industry enterprises.

The author's methodical approach to aggregation of quantitative limits of estimation of influence of forecast parameters of strengthening of economic safety of the enterprises of the 
DOI: 10.14807/ijmp.v11i9.1422

food industry is constructed and offered; which is based on a mathematical model that takes into account a set of grouped indicators of economic security on the impact of important factors on the level of profitability of the food industry, and can be used to implement management decisions to enhance and stimulate further development.

Based on the functional-target description of the structure of the economic security management system of the enterprise it is shown that the effective implementation of the economic security management process becomes possible with the support of a set of economic and mathematical models, which are combined into a single set of models. contains three blocks: formation of information space of research; assessment and analysis of economic security of the enterprise; formation and analysis of decisions on economic security management of the enterprise.

To implement the proposed set of models, the data of statistical reporting of four food industry enterprises of Chernivtsi region of Ukraine were used.

According to the proposed set of models, a sample of safety indicators was formed to assess the economic security of the enterprise, the author's information model of economic security assessment was proposed, the purpose of which is to form and filter the previous indicators most important for economic security assessment. The reliability of the obtained results, conclusions and proposals is confirmed by the calculations and the use of a significant amount of empirical material.

The tasks set in the research were solved using the following methods: statistical and economic - to compare, group and display empirical indicators (to identify the specifics and special features of the formation of economic security); time series (in the study of changes in indicators over time); graphic (for a visual representation of the results of the study); calculation and constructive (when forecasting possible options for the development of economic security processes taking into account changes in various factors); comparison (in order to compare data in the dynamics; grouping (to determine the dependence of indicators on each other, averages and relative values in the analysis of calculations of the level of economic security).

\section{RESULTS AND DISCUSSIONS}

The food industry in the region is more than 80 enterprises, which produce more than 100 different types of products. These enterprises account for almost a quarter of the total industrial output, accounting the fifth part of employees in the industry. Among the most powerful enterprises of food and beverages producers there are PE "Kolos", PJSC "Meat of Bukovyna" of Novoselytskya Poultry Plant, PJSC "Chernivtsi Bakery”, PJSC "Chernivtsi Oil 
DOI: 10.14807/ijmp.v11i9.1422

and Fat Plant", PJSC "Bukovynaproduct", "Gals-2000” LLC, "Apollo" LLC, "Gals LTD” LLC, PE “Antares 7”, SE Nepolokivskyi plant of bread products and others.

The food industry is the main processing unit of the agro-industrial complex. It is closely linked to agriculture through industrial relations. The stable and efficient functioning of food and beverage enterprises depends directly on the timely and regular loading of their production facilities, which in turn depends on the agricultural production volume.

In the production structure of the foreign trade in 2018, food products accounted a small share i.e. $3.8 \%$ of total exports and $3.9 \%$ of imports. Its exports decreased by 2.1 times compared to the previous year and amounted to USD 6.4 million, while imports increased by 2.7 times to USD 7.7 million. In 2018, the entities of the region carried out operations on export of finished food with partners from 9 countries of the world, imports from 19 countries.

The largest products of the food industry from the region were exported by "Doehler Bukovina” LLC, “OLBI-ROS” LLC, PJSC “Chernivtsi Bakery”, PE "Bukoviyna Trek”, and "Argo" LLC. The largest imports of food products were received by PE "Kolos", "Darvit" LLC, and PJSC "Meat of Bukovyna" of Novoselytsya Poultry Plant.

In the market conditions the need for solving the problems of the food industry enterprises economic security has increased significantly. That is why it is necessary to use economic and mathematical approaches to solve these problems. Using statistical analysis data can solve the problem of successful functioning in the conditions of severe competition, so companies feel the need to analyse the available information and introduce new forms, methods to stabilise the enterprise economic security.

Thus, in many statistical problems, it is advisable to express the dependent variable as a linear function of the independent variables. For this purpose, a regression analysis was used to summarize the data and evaluate the strengthening or weakening of economic security as dependencies between the variables. And also using it to predict new values of the dependent variable and based on the statistics survey.

Statistics is not always accurate and clearly reflect the food industry work, they are not stable and therefore the use of statistics and their methods does not produce accurate results. That's why we used simple linear regression models that establish a direct linear relationship between two variables. For example, it can be used in the advertising, production and sales increase and its realisation. Here, one of the variables is considered as a dependent variable $(y)$ and is regarded as a linear function of the independent variable $(x)$. 
DOI: 10.14807/ijmp.v11i9.1422

In general, a simple sample regression model is written as follows:

$y=b_{0}+b_{1} x+e$,

where $y$ is an observation vector of the dependent variable;

$Y=\left\{Y_{1}, Y_{2}, \cdots Y_{n}\right\}$

$x$ is an observation vector of the independent variable;

$x=\left\{x_{1}, x_{2}, \ldots x_{n}\right\}$,

$b_{0}, b_{1}$, are the unknown parameters of the regression model;

$e$ is a vector of random variables (errors);

$e=\left\{e_{1}, e_{2}, \ldots e_{n}\right\}$

Model (1) is a linear regression function which graph is straight on a plane;

- $b_{o}$ is the intersection of the line with the y-axis;

- $b_{1}$ is the tangent of the angle of inclination of the straight line to the abscissa (usually if we abstract from a random variable $e$, that will go to 0 ).

To record this function we need to find and evaluate unknown parameters $b_{0}, b_{1}$ of this model. Now we'll consider the equation of the line in the general form $\hat{y}=b_{0}+b_{1} x$. In this case, there are many lines of this kind that can be drawn through many observation points. In order to determine which, one to choose from the set of these lines, the first selection criterion must be determined to select the best line in terms of the given criterion.

The optimal criterion is the criterion for minimizing the sum of squares of deviations $e_{i}=y_{i}{ }^{-} \hat{o}_{i}$. It is logical and appropriate that the line should be carried out in such a way as to $\operatorname{minimize} \sum_{i=1}^{n} e_{i}^{2}$

Minimizing function

$$
\sum_{i=1}^{n} e_{i}^{2}=\sum_{i=1}^{n}\left(y_{i}-b_{0}-b_{1} x_{i}\right)^{2}=b\left(b_{0}, b_{1}\right)
$$

which is a function of two unknowns $b_{0} \mathrm{i} b_{1}$, it gives the following formula for parameter $b_{1}$ (slope): 
$b_{1}=\frac{\frac{1}{n}\left(\sum_{i=1}^{n} x_{1} y_{1}\right)-\bar{x} \cdot \bar{y}}{\frac{1}{n} \sum_{i=1}^{n} x_{i}^{2}-(\bar{x})^{2}}$,

where $\bar{x}=\frac{1}{n} \sum_{i=1}^{n} x_{1}, \bar{y}=\frac{1}{n} \sum_{i=1}^{n} y_{i}$.

The parameter $b_{0}$ (ordinate of intersection point) is given by the next formula:

$b_{0}=\bar{y}-b_{1} \cdot \bar{x}$.

To determine the level of economic security of food industry enterprises and to regulate aspects by comparing the activities of PJSC "Chernivtsi Oil and Fat Plant", PJSC "Chernivtsi Bakery", PE "Kolos" and "Doehler Bukovina" LLC with the help of linear regression as (1).

The purpose of strategic ensuring of the enterprises economic security is the enterprise adaptation to the situation of the resource markets, increase of its profitability level, corresponding of the technological base with technological progress, etc. Strategic support for the financial component of economic security is to increase the level of enterprise profitability and to ensure maximum profit, by other equal conditions, over the long term, by maintaining financial security. Strategic provision of an innovative component of economic security reflects the compliance of the enterprise development with technological progress, which consists, first of all, in the intensification of production and economic activity to improve the goods quality and meet the needs of consumers and etc.

The economic security aspects are divided into 11 main components, which are interconnected and interdependent. They determine $100 \%$ of the variance of the food industry safety indicator (KOZACHENKO, 2013; VASYLTSIV, 2008; IHNASHKINA; SHATOKHIN, 2019; MASLAK; HRYSHKO,2013).

By predicting the food industry for the next 5 years, we used the possibility of three scenarios to strengthen the economic security: pessimistic, realistic and optimistic.

The economic security level of the food industry will improve as the financial situation improves. The financial component is directly proportional to the economic security of the enterprise, that is, with the improvement of the enterprise financial condition, its economic security is strengthened. The forecast is made using the regression equation for the data of the food industry enterprises of Chernivtsi region (Table 1). 
INDEPENDENT JOURNAL OF MANAGEMENT \& PRODUCTION (IJM\&P)

http://www.ijmp.jor.br

v. 11, n. 9, Special Edition (Baltic States), November 2020

ISSN: 2236-269X

DOI: 10.14807/ijmp.v11i9.1422

Table 1: The profit forecast of the food industry enterprises of Chernivtsi region for 20172021

\begin{tabular}{|l|l|c|c|c|c|c|c|}
\hline \multirow{4}{*}{$\begin{array}{c}\text { Company } \\
\text { name }\end{array}$} & $\begin{array}{l}\text { Forecast } \\
\text { scenario }\end{array}$ & \multicolumn{2}{|c|}{ Yearly prediction } \\
\cline { 3 - 8 } & & $\mathbf{2 0 1 6}$ & $\mathbf{2 0 1 7}$ & $\mathbf{2 0 1 8}$ & $\mathbf{2 0 1 9}$ & $\mathbf{2 0 2 0}$ & $\mathbf{2 0 2 1}$ \\
\hline \multirow{2}{*}{$\begin{array}{l}\text { PJSC } \\
\text { «Chernivtsi }\end{array}$} & Pessimistic & & 153042 & 217468 & 254896 & 286324 & 320752 \\
\cline { 2 - 8 } $\begin{array}{l}\text { Oil and Fat } \\
\text { Plant» }\end{array}$ & Realistic & 166965 & 217468 & 254896 & 286324 & 320752 & 355180 \\
\cline { 2 - 8 } & Optimistic & & 251896 & 286324 & 320752 & 355180 & 389608 \\
\hline $\begin{array}{l}\text { PJSC } \\
\text { «Chernivtsi } \\
\text { Bakery» }\end{array}$ & Pessimistic & & 1117073 & 1175063 & 1233053 & 1291043 & 1349033 \\
\cline { 2 - 8 } & Realistic & 179818 & 1175063 & 1233053 & 1291043 & 1349033 & 1407023 \\
\cline { 2 - 8 } "Doehler \\
$\begin{array}{l}\text { Bukovina" } \\
\text { LLC }\end{array}$ & Optimistic & & 1233053 & 1291043 & 1349033 & 1407023 & 1465013 \\
\cline { 2 - 8 } & Realistic & 115344 & 145733 & 182314 & 218895 & 255476 & 292057 \\
\cline { 2 - 8 } & Optimistic & & 182314 & 218895 & 255476 & 292057 & 328638 \\
\hline \multirow{2}{*}{ PE "Kolos" } & Pessimistic & & 183973 & 166951 & 149929 & 132907 & 115885 \\
\cline { 2 - 8 } & Realistic & 166520 & 166951 & 149929 & 132907 & 115885 & 98863 \\
\cline { 2 - 8 } & Optimistic & & 149929 & 132907 & 115885 & 98863 & 81841 \\
\hline
\end{tabular}

Source: by the authors according to data of domestic enterprises

Analysing the forecast of the food industry companies, we can say that for PE "Kolos" it is not comforting at all, we observe that the net income from the sale of products (goods, works) is decreasing. PJSC "Chernivtsi Bakery", PJSC "Chernivtsi Oil and Fat Plant" and LLC "Doehler Bukovina" will have higher net income from sales of products (goods, works).

Positive tendencies in strengthening the economic security of the studied enterprises will be observed in increasing the level of innovation component, as well as implementation of enterprise activity planning by goals and results, competitively distributing finances between programs and projects, as well as monitoring the results achievement, determining responsible for not fulfilling the tasks. It is advisable to identify specific and priority problems when deciding which can effectively combine program goals and ways to achieve them. It is necessary to study the threats that accompany the enterprise existence.

Based on the functional and target description of the structure of the economic security management system of the enterprise, it is shown that the effective implementation of the economic security management process becomes possible with the support of a set of economic and mathematical models, which are combined into a single set of models of assessment and analysis of the enterprise economic security (Figure 1). 
DOI: 10.14807/ijmp.v11i9.1422

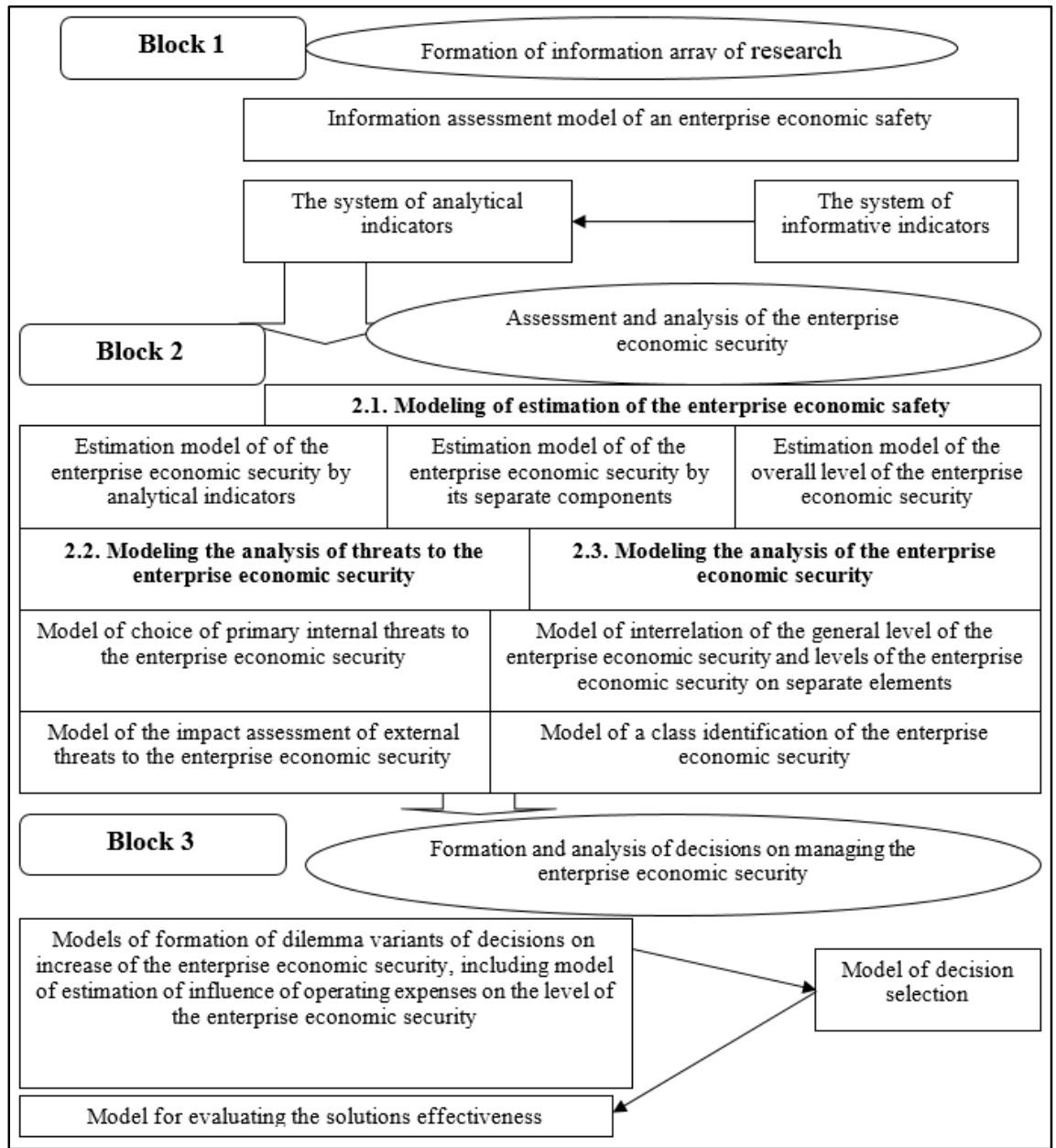

Figure 1: The complex of analysis and estimation models of the enterprise economic security of the food industry

Source: by the authors

The offered complex contains three blocks: formation of research information space; assessment and analysis of the enterprise economic security; formation and analysis of decisions on management of the enterprise economic security.

The purpose of the first block is to generate an array of indicators most important for assessing economic security, using a developed information model.

The aim of the second block is to develop models for assessing and analysing the enterprise economic security. At this stage, all models are combined into three modules, which, on the basis of the respective models, provide a general assessment of the enterprise's economic security and identify dominant threats to economic security. The first module of economic security assessment contains models, the purpose of which is to calculate the values of indicators, which allows tracing the change in both the overall level of the enterprise economic security and its components. 
DOI: 10.14807/ijmp.v11i9.1422

The second module contains models for selecting the dominant threats to the enterprise economic security and a model for assessing the impact of external threats on the enterprise economic security. The first pattern of this module performs the ranking of threats from the internal environment by their impact on the overall level of economic security of the enterprise, which allows analysing and identifying the most important factors that are potential security threats. The target of the second model is to assess the impact of external threats on the overall level of the enterprise economic security.

The third module examines the impact of individual security components on its overall level, using a model of the relationship between the overall level of economic security of an enterprise and the levels of enterprise security by individual components. The following model of this module is the model of the classes' identification of the enterprise economic security which allows receiving information about a security class in the current and future periods.

The purpose of the third block is to formulate many decisions on managing the economic security of an enterprise based on information about its class and threats. These decisions should be included in the system of prevention and elimination of destabilizing influence of threats to the economic security of the enterprise.

For the implementation of the proposed set of models, the statistical reporting data of 4 food industry enterprises of Chernivtsi region were used. According to the proposed set of models (Fig. 1), the selection of safety indicators is a primary task in assessing the economic security of an enterprise, the results of which will directly affect the safety management effectiveness.

To address this challenge, an information model of economic security assessment is proposed, the purpose of which is to formulate and filter out previous indicators that are most relevant to security assessment. By applying these measures to ensure economic security at the enterprise, the likelihood of its further life cycle increases, because only at the expense of a well-organized economic security system, the company will be able to actively compete in the competition for its place in the market. Consider the economic security goals for food businesses, depending on the life cycle stage.

The paper determines that the situation in the enterprise is characteristic of a recession stage with a high probability of a bankruptcy situation. In the process of managing the enterprise economic security, it is necessary to take into account the existing level of economic security in together with the tendencies of its changes in space and strategic priorities and 
DOI: 10.14807/ijmp.v11i9.1422

opportunities in its provision direction. As it was noted earlier, the purpose of the first block is to develop a system of indicators most important for assessing economic security, using a developed information model. The matrix of changes in the economic security level allows you to position the company and make a choice of its development depending on the change in the level of economic security of food industry enterprises (Table 2).

Table 2: Matrix of the strategy choice of economic safety management of the food industry enterprises

\begin{tabular}{|c|c|c|c|c|}
\hline \multirow{2}{*}{$\begin{array}{c}\text { The direction of } \\
\text { change in the } \\
\text { degree of the } \\
\text { enterprise } \\
\text { economic security }\end{array}$} & \multirow[b]{2}{*}{$\begin{array}{l}\text { Features of the degree of the enterprise } \\
\text { economic security }\end{array}$} & \multicolumn{3}{|c|}{$\begin{array}{l}\text { Intensity of readiness for } \\
\text { strategic change }\end{array}$} \\
\hline & & Low & Average & High \\
\hline $\begin{array}{l}\text { The degree of the } \\
\text { enterprise } \\
\text { economic security } \\
\text { is stable }\end{array}$ & $\begin{array}{l}\text { Appears on the condition of immediate } \\
\text { changes in external and internal factors: } \\
\text { decrease in financial capacity while } \\
\text { weakening the influence of external } \\
\text { factors; freezing of internal factors under } \\
\text { conditions of external stability; capacity } \\
\text { building is levelled by the ability to } \\
\text { influence external factors }\end{array}$ & $\begin{array}{l}\text { Passive } \\
\text { strategy }\end{array}$ & $\begin{array}{l}\text { Positive } \\
\text { image } \\
\text { strategy }\end{array}$ & $\begin{array}{l}\text { Expansion } \\
\text { strategy }\end{array}$ \\
\hline $\begin{array}{c}\text { The degree of the } \\
\text { company economic } \\
\text { security moderately } \\
\text { decreases }\end{array}$ & $\begin{array}{l}\text { The enterprise prospects weaken over time } \\
\text { (the influence of external factors is not } \\
\text { significant); since the potential of the } \\
\text { enterprise does not change over time, it } \\
\text { gradually ceases to withstand the pressure } \\
\text { caused by the action of external factors. }\end{array}$ & $\begin{array}{c}\text { Protective } \\
\text { strategy }\end{array}$ & $\begin{array}{c}\text { Stabilizati } \\
\text { on } \\
\text { strategy }\end{array}$ & $\begin{array}{l}\text { Positive } \\
\text { image } \\
\text { strategy }\end{array}$ \\
\hline $\begin{array}{c}\text { The degree of the } \\
\text { company economic } \\
\text { security is falling } \\
\text { rapidly }\end{array}$ & $\begin{array}{l}\text { This is a situation that leads to the loss of } \\
\text { the enterprise opportunities. The company } \\
\text { does not have time to respond to changes } \\
\text { caused by the action of external factors, } \\
\text { pays insufficient attention to its economic } \\
\text { condition. }\end{array}$ & \begin{tabular}{|c|} 
A strategy \\
based on \\
conventio \\
nal \\
capabilitie \\
$\mathrm{s}$ \\
\end{tabular} & $\begin{array}{c}\text { Crisis } \\
\text { strategy }\end{array}$ & $\begin{array}{l}\text { Stabilizatio } \\
\text { n strategy }\end{array}$ \\
\hline $\begin{array}{c}\text { The degree of the } \\
\text { company economic } \\
\text { security is } \\
\text { Moderately } \\
\text { increasing }\end{array}$ & $\begin{array}{c}\text { Internal components of economic security } \\
\text { are balanced and the company is } \\
\text { financially stable, or when the situation is } \\
\text { in its favour. }\end{array}$ & $\begin{array}{l}\text { Conservat } \\
\text { ion } \\
\text { strategy }\end{array}$ & $\begin{array}{l}\text { Positive } \\
\text { image } \\
\text { strategy }\end{array}$ & $\begin{array}{c}\text { Expansion } \\
\text { strategy }\end{array}$ \\
\hline $\begin{array}{c}\text { The degree of the } \\
\text { company economic } \\
\text { security is growing } \\
\text { rapidly }\end{array}$ & $\begin{array}{c}\text { Synergistic result (strengthening the } \\
\text { internal factors influence at weakening on } \\
\text { external action). }\end{array}$ & $\begin{array}{c}\text { Protective } \\
\text { strategy }\end{array}$ & $\begin{array}{l}\text { Positive } \\
\text { image } \\
\text { strategy }\end{array}$ & $\begin{array}{l}\text { Expansion } \\
\text { strategy }\end{array}$ \\
\hline
\end{tabular}

Source: by the authors

It reflects the factors interaction and allows determining the direction and causes of changes in the economic security of the enterprise over time. In each case, the company has three scenarios (stable condition, improvement, deterioration), each of which has specific causes and needs specific recommendations.

Ensuring the economic security of an enterprise is a continuous process aimed at protecting the economic interests of the owner and the enterprise, which is carried out by the 
DOI: 10.14807/ijmp.v11i9.1422

security entities within the limits defined by the owner and the legislation in force. Based on this, the content, goals, objectives, principles and algorithm of measures of its compliance at the enterprise should be stated in the system of economic security management.

Trends changes in the level of the enterprise economic security over time and analysis of the reasons for such changes provide the necessary information to choose the right strategy for managing the economic security of the enterprise. To determine the trend of change in the enterprise economic security in time it is advisable to use a matrix, based on the following assumptions:

- the market environment in which businesses operate is dynamic;

- the enterprise is in the information space, able to identify changes in the external environment and make predictions for the future;

- the enterprise has a certain level of potential and has reached a specific level of the enterprise economic security, which is formed by the interaction of the influence factors of internal and external environment. Changes in the level of economic security are initiated by the enterprise itself, and external factors are independent of the enterprise;

- dependence of the economic security level on the determinant of time can have three possible scenarios: the level decreases, the level of a certain time is unchanged, the level increases (raises). If an enterprise does not purposely influence the level of economic security (retains its existing status and does not pursue a growth policy), then its level of economic security tends to decline over time. If externalities are weakened, but they do not yet destroy the potential of the enterprise, then the level of economic security may remain at the same level for some time. If external factors reinforce the enterprise internal efforts, creating a synergistic effect, then the level of economic security increases;

- it is assumed that the change in economic security takes place gradually: "stable level" - "moderate change" - "strong change". Minor changes are accepted in the absence of changes;

- the best development scenario for an enterprise is to increase (steadily increase) the level of economic security.

Therefore, a methodical approach to the aggregation of quantitative boundaries of estimating the impact of forecasting parameters of strengthening the economic security of food 
DOI: 10.14807/ijmp.v11i9.1422

industry enterprises has been developed and proposed; which is based on a mathematical model that takes into account the aggregate of economic security indicators on the impact of important factors on the level of a food industry profitability, and can be used to implement management decisions to enhance and stimulate the further development of the enterprise.

The management system in the areas of the concept of safe functioning of the enterprise should be in a state of constant expectation of signals from the factors of external and internal environment, which trigger them economic mechanism of occurrence of a negative or positive change in the food industry (Figure 2).

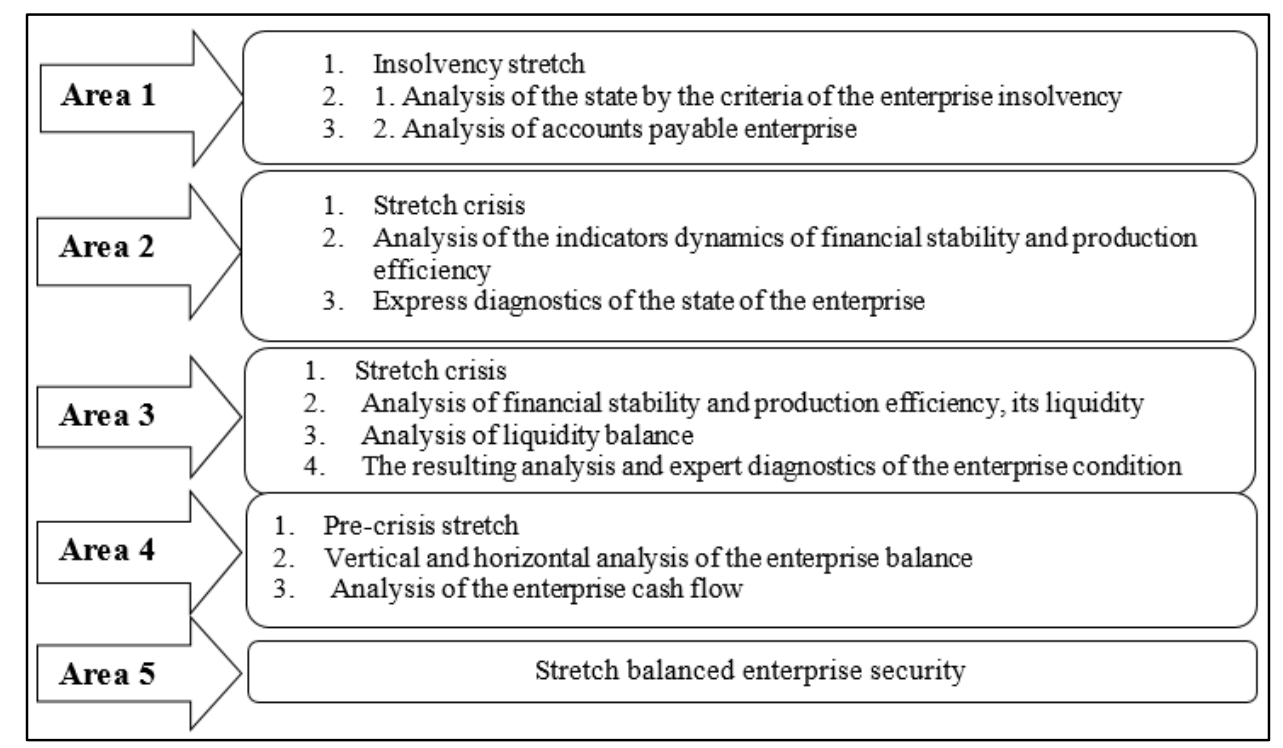

Figure 2: The algorithm of forming the mechanism of enterprises economic security of food industry

Source: by the authors

The mechanism of enterprise economic security management should ensure timely identification of various hazards, forecasting their consequences, identifying methods of gathering and providing information to the management centre, which decides on what to do next.

The proposed algorithm for forming the mechanism of economic security of food industry enterprises is conventionally divided into five areas: insolvency stretch, crisis stretch and its condition, pre-crisis stretch, balanced enterprise stretch. Within the spheres the following functions of the mechanism are realized: analysis of the state according to the criteria of the enterprise insolvency, analysis of the enterprise accounts payable, analysis of the dynamics of the financial stability indicators and production efficiency, rapid diagnostics of the enterprise state, analysis of financial stability and efficiency of production, its liquidity, analysis of liquidity balance, the resultant analysis and expert diagnostics of the enterprise state, 
DOI: 10.14807/ijmp.v11i9.1422

vertical and horizontal analysis of the enterprise balance, analysis of cash flow under friendship.

In combination of all spheres, it is possible to obtain the highest level of economic security of food industry enterprises, which is the subject of synchronization of its formation mechanism and functional components. Synchronization can be seen as a process of ensuring that the mechanism actions and economic security responses are consistent with the expected outcome.

We agree with the scientist SIVOLAP (2014) that the enterprise security service can be distinguished as a separate segment of the organizational structure of the enterprise, which interacts with the whole structure. The service can be described as a complex of management, legal, organizational, security, insurance and other measures to protect the enterprise from unlawful encroachment. The entire range of economic security measures is vested in the security services of SIVOLAP (2014).

The enterprise security service must be based on the size of the enterprise as well as the ownership. The main functions that will be performed by the enterprise security service: protection of production and economic activity, which is a trade secret; prevention of unreasonable access to company information; organization of the regime of activity all processes; possible channels localization of leakage of confidential information during operation; security of premises, offices, equipment, products, raw materials; the manager and administrative staff protection; assessing the marketing situations and misconduct of competitors and attackers.

Accordingly, in the security service documents, the following objects of protection should be identified: personnel; tangible and financial values; information resources.

Creating your own security service is, in practice, a major challenge, as each entity is as individual as its work. In practice, it is possible to recommend to businessmen a number of measures to create a security service:

1) Deciding on setting up your own security service.

2) Defining the main tasks of the security service.

3) Development of regulations on security service, structure and staff creation.

4) Qualified personnel recruitment.

5) Conclusion of non-disclosure contracts in case of release. 
The above mentioned points to the need to set up an enterprise security service to protect against external factors. The essence of the implementation of the project structure of the enterprise economic security service determines how much the created system meets the requirements of improving the enterprises activity (Figure 3).

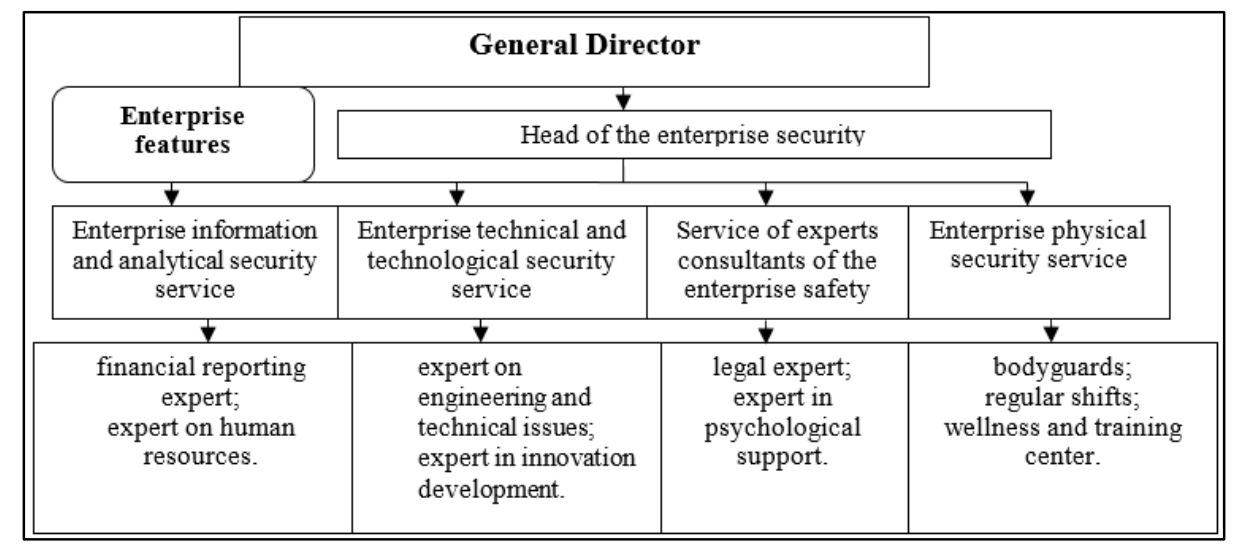

Figure 3: The project structure of the enterprise economic security service Source: by the authors

To compare the effectiveness of the funds use for the enterprise security service in the base year and project calculations, we use the following table 3 .

Table 3: Cost-effectiveness of the security service for PJSC "Chernivtsi Bakery"

\begin{tabular}{|l|c|c|c|c|}
\hline \multicolumn{1}{|c|}{ Indicators } & Basic & Design variant on & \multicolumn{2}{c|}{ Deviation } \\
\cline { 4 - 6 } & version & 2017 & absolute, +, - & relative, \% \\
\hline Security service costs, thousand UAH. & 3300 & 3450 & 150 & 4,5 \\
\hline Profit from the security service, thousand & 3562,5 & 4324,3 & 761.8 & 21,4 \\
\hline UAH. & 1,07 & 1,25 & 0,18 & 16,8 \\
\hline Security service efficiency, thousand UAH. & &
\end{tabular}

Source: by the authors

The calculations show that the increase in security costs for PJSC "Chernivtsi Bakery" by 150 thousand UAH in accordance with the performance indicators of these funds, it will increase the profit of the enterprise by 761,8 thousand UAH and it will increase service efficiency by $16.8 \%$. Thus, the economic effect (E) of implementing the proposed measures is the difference between the additional costs and the increase in profits from the proposed measures:

$\mathbf{E}=\left(\Pi_{\Pi}-\Pi_{\boldsymbol{\sigma}}\right)-\left(\mathbf{B P}_{\Pi}-\mathbf{B P}_{\boldsymbol{\sigma}}\right)$,

where $\Pi_{\Pi}-$ profit after offers implementation;

$\Pi_{\sigma}$ - basic profit;

$\mathrm{BP}_{\Pi}-$ design costs for advertising;

$\mathrm{BP}_{\sigma}-$ advertising costs in the base period.

So, $E=(4324,3-3562,5)-(3450-3300)=761,8-150=611,8$ thousand UAH. 
DOI: 10.14807/ijmp.v11i9.1422

Thus, the calculations confirmed the feasibility of implementing the proposed measures. This calculation for each type of enterprise is individual.

Economic security management should be designed as a subsystem of the general management system, which is closely related to the solution of other problems of the enterprise, and therefore it has to be subordinate. In general, the mechanism of economic security management can be described using a scheme which main parameters describe the content of management actions, their leading functions and options for possible solutions. The block diagram of the mechanism of the enterprise economic security management gives the most general idea of how the system works and on what its state FEN` (2018) depends.

Stage I. In the first stage of defining the mission and strategic goals of an enterprise in the management of its economic security, it should be taken into account that the purpose is influenced by both external factors (external requirements, needs, programs) and internal factors (needs, opportunities, programs system and its elements, performers). However, the latter factors are objectively influencing the process of goal formation, especially when they are used in the management systems of the "goal" definition as a means of encouraging action.

The goal can be formed on the basis of interactions, disputes, or coalitions, both between external and internal factors that have existed before and have been in constant motion and integrity. The radicality assessment and duration of changes in the external and internal environment is the basis for creating and controlling the balance of the enterprise with the external environment, the analysis of enterprise capabilities. It is offered to identify the severity of threats to the enterprise using the threat-loss matrix, which defines the position (critical, high, medium, low and minimum levels of danger) based on two reference-probabilities i.e. the threat occurrence and the possibility of losing the achieved level of economic security.

The assessment is conducted in two blocks: in the first stage, the threat possibility is suggested to be determined by the expert method using the SAATI (1993) scoring scale.

In the second stage, according to the correlation-regression analysis, the position of the selected threats is determined by the criterion of the degree of influence on the dynamics of the economic security level of the studied enterprises. At the same time, possible threats to the economic security of the enterprise are identified by major subsystems.

Thus, the deviation of the economic security state from the equilibrium state depends not only on the factors of influence, but also on the internal ability to counteract their influence. In general, the more open the system to external influences, the faster and with fewer losses it 
DOI: 10.14807/ijmp.v11i9.1422

adapts to changes in the environment. Due to the fact that the enterprise, as any other, is an open system, it should be considered that the adaptation process is a mechanism that allows establishing a clear cause and effect relationship between the intensity of resource flows and the level of internal self-organization of the system. Under the influence of external factors, the open system is constantly transformed around an empirically weighted average attractor state.

Thus, the management of enterprise economic security should be based on the principles of ensuring its rational level, which does not limit the possibility of the system progressive development and at the same time reserves the resources for maintaining the stability of the boundary conditions, counting the dualistic nature of the impact of investment and innovation activities on the state of economic security. Considering the above mentioned, it should be emphasized that an important element and purpose of effective management of the enterprise economic security is to ensure its rational level.

Linguistic and semantic analysis of the concept "rationality" showed that rationalization is a rational explanation, logical reasoning, rationalistic explanation, rationalization, deprivation of irrationalities (in mathematics).

Rationale of law is the law foundation. In particular, in English, the term "ratio" is translated as a coefficient, proportion, ratio (ratio of exchange), rate, diet. The verb "ratiocinate" means thinking, reckoning, consider logically, seeking the necessary explanations, trying to justify something. The adjective "rational" means mental, thinking, endowed, sensible, appropriate, and practical.

We suggest understanding rationality in the context of ensuring the level of economic security as a balance of timely, adequate response of the enterprise to changes in the external and internal environment, i.e. its correspondence with the potential devastating consequences of the threat.

Stage II. The hierarchy analysis method is offered to decide on the priority of an enterprise reaction to self-preservation, stabilization, competitive formation, innovative or long-term potential position within the enterprise economic security management. This analysis method was first developed by SAATI (1993) and is widely used in the analytical planning by well-known companies in Western countries, such as Ford, Microsoft.

The scope of this method is the resources allocation, prioritization in the selection of alternative solutions, and cost-effectiveness analysis. The process of applying this method consists of three steps. The first step is to structure the selection problem, which results in the 
DOI: 10.14807/ijmp.v11i9.1422

decision-making process being presented as a subordinate hierarchy or network. In elementary form, a hierarchy is formed from the top (goal) through intermediate levels that is criteria to the lowest level, which is a set of alternatives and a system of relationships that demonstrate the mutual influence of factors (criteria) and alternatives. Thus, the basis of the first stage is the application of a systematic approach to the problem of decision-making, which is realized with the help of such provisions (Figure 4).

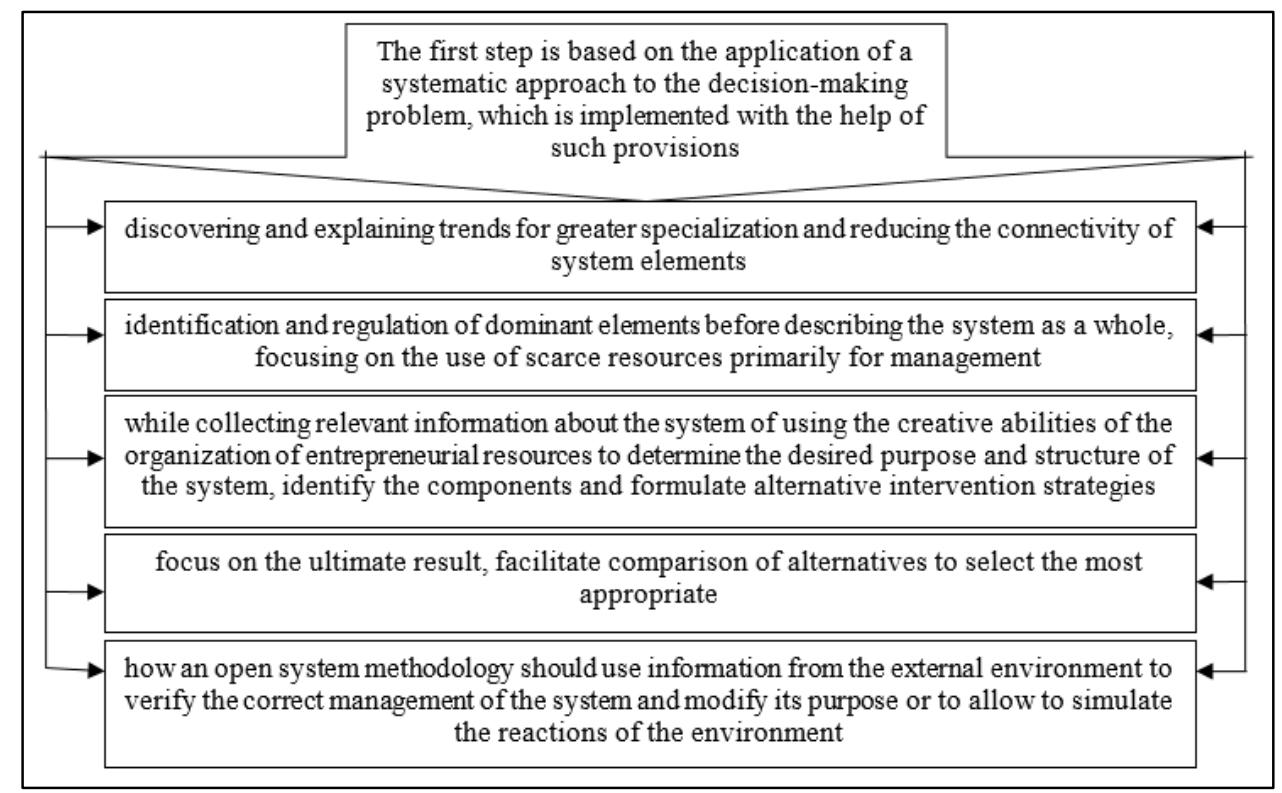

Figure 4: The provisions of the first stage for application a systematic approach to food industry enterprises

Source: by the authors

In the second stage, the priorities of the criteria are established and each alternative is evaluated against the established criteria, using the paired comparisons method of the elements relatively to their influence on the overall characteristic for them. A pairwise comparison system produces a result that can be represented in the form of an inversely symmetric matrix. The evaluation is performed on the basis of the method proposed by the author of the intensity scale from 1 to 9 . Thus, the method of hierarchy analysis provides to decompose a complex decision-making process by separating the elementary, formalized components of this process. In the third stage of the hierarchy method implementation, using the mechanism of determining the eigenvectors of the priority matrixes and the algorithm of calculating global priorities of the alternatives with respect to the goal, the final rating is calculated i.e. the position of the priority of the alternatives in the decision making process with the mark of the above goal.

Thus, the hierarchy method is based on a systematic approach and peer review, and at an intermediate stage it is possible to form a rating of the local priorities of the criteria for the 
DOI: 10.14807/ijmp.v11i9.1422

aim. The possibility of checking the contradictions of experts' evaluation by determining the level of consistency and their possible correction is another advantage of the hierarchy method.

According to this methodology, we will determine the priorities of alternatives to qualitative criteria of the enterprise economic security system. To this end, alternatives should be considered for the purpose to which they are conducive.

The alternatives in our case are the reactions of the enterprise regarding selfpreservation, stabilization, formation of competitive, innovative position or position of providing long-term potential within the framework of economic security management of the enterprise. Local criteria are qualitative characteristics of the economic security management system by MASLAK et.al (2013).

The mechanism of ensuring the economic security of the enterprise is regarded as a set of managerial, economic, organizational, legal and motivational ways of harmonizing the interests of the enterprise with the interests of environmental subjects, whereby, with the help of the enterprise activity peculiarities, they are guaranteed for getting a profit, the value of which is at least sufficient, for holding the enterprise in economic security (Figure 5).

The concept of creation the enterprise economic security mechanism implies that the basis of the mechanism is the formation of the system of priority interests of the enterprise, followed by their harmonization with the interests of the subjects of the external environment interaction with the enterprise.

Monitoring should cover both operational aspects of enterprise management and be a strategic management tool. There is a certain scientific "vacuum" in the field of methodological developments of the organization and functioning of the monitoring system at industrial enterprises by MISHCHENKO (2012).

The concept of "monitoring" includes the continuous, systematic collection of information to monitor and control the development of a particular phenomenon or process, as well as its prediction.

Monitoring of the enterprise as a whole and its most important spheres, as an effective tool for improving the efficiency of enterprise management, has not yet become widespread in Ukrainian practice by MISHCHENKO (2012). 
DOI: 10.14807/ijmp.v11i9.1422

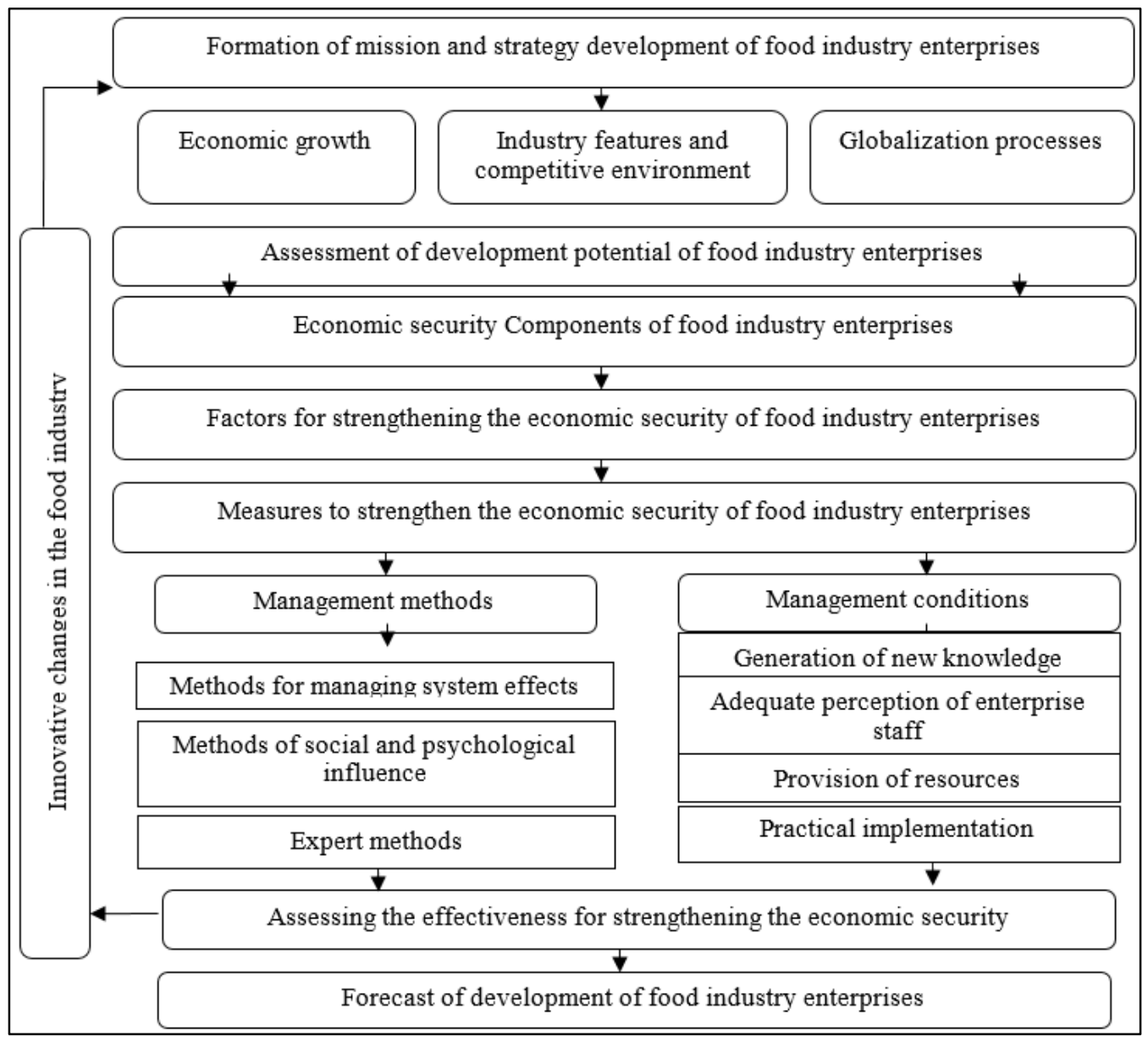

Figure 5: Mechanism for strengthening the economic security of food industry enterprises Source: by the authors

Monitoring the economic security of an enterprise is connected with the fact of determining the profitability of its production and economic activity, since the main source of ensuring sustainable economic development is profit.

Therefore, first of all, it is necessary to determine the presence of profit in the enterprise according to the financial statements for the last period of its activity.

The organization of the system of monitoring the state and trends of mutual settlements in the enterprise is important for improving its economic security for the following reasons:

a) since the balance of payments has a significant impact on economic security, the monitoring results allow us to determine certain threshold levels of obligatory status characteristics and certain indicators of financial and economic status when certain management decisions need to be taken to avoid unduly reducing economic security;

b) the monitoring of the settlement status provides feedback in the company settlement system. The success of any management actions, strategies and plans implementation is determined not only by the quality of their preparation, but also by the observing their 
DOI: 10.14807/ijmp.v11i9.1422

implementation status, due to changes in the characteristics of the mandatory statuses of the enterprise and those indicators of financial and economic status that are related to the enterprise economic security and mutual settlements in which it participates.

Structurally, the system of monitoring the economic security of the enterprise consists of an information database, analytical tools and a bank of targeted programs for safe development. And if the first and third elements of the monitoring system are already well developed in scientific research, then the choice of analytical means of information analysis still has controversy.

The main subjects of the mutual settlements monitoring are: the enterprise, its management apparatus, as well as production and auxiliary units. Participation of all units in monitoring is obligatory, and the management of the enterprise ensures confidentiality and reliability of provided the information. In the process of managing settlements in terms of the enterprise economic security, it is logical to distinguish six time levels: current; operative; medium term (from one quarter to one year); tactical; long-term (from one year to three); strategic.

The separation of such levels is due to the fact that the adjustment tools of the settlement policy must be differentiated depending on the level of application. On the other hand, the factors that affect the current situation are different in the medium and long term prospect.

Therefore, before conducting the monitoring itself, it is necessary to determine the economic security status of the food industry.

The content and sequence of monitoring at the food industry should consist of the following steps:

1) enterprise identification (economic entity) and the object of monitoring;

2) formation of a system of technical and economic indicators for assessing the economic security of an enterprise, considering the specifics of its functioning;

3) collection and preparation of information characterizing the status of the observed object; identifying factors that characterize prospective directions of enterprise development;

4) modelling and formation of scenarios or strategies for the enterprise development;

5) calculation of technical and economic indicators of the enterprise for the entire depth of the predicted period; 
DOI: 10.14807/ijmp.v11i9.1422

6) analysis of economic security indicators;

7) development of proposals for the prevention and neutralization of threats to the enterprise economic security.

The offered methodical approach and tools of analysis and diagnostics of the enterprise state allow with sufficient completeness to investigate a set of factors that threaten the economic security of the enterprise, to reasonably and purposefully organize and perform the necessary monitoring, to systematically analyse the dynamically changing socio-economic situation, to conduct technical and economic decisions.

Based on the obtained data about diagnostics of the enterprise economic security and the proposals on improvement system of economic security management, the main directions of ensuring the economic security of the food industry enterprises for the next period are:

1) the financial stability and independence achievement, development of measures for anti-crisis financial management;

2) the effective management and marketing introduction, including the functions which should be the organization and implementation of protection the confidential information; organization of collection, accumulation, automated accounting and analysis of information on economic security issues; conducting inspections in the structural units of the enterprise and providing them with practical assistance in the safety of their activities; checking the personnel for compliance with the rules of economic, information and physical security; improvement of work with personnel in selection, appointments, job transfer and its professional development; collecting, processing, storing, analysing information about counterparties in order to prevent agreements with unscrupulous partners;

3) the balance between financial security and other components of the enterprise economic security.

Taking into account the indisputable interrelation between internal and external threats and functional components of the enterprise economic security, it becomes possible to determine the directions of strengthening the latter for the food industry of Chernivtsi region, which will provide the main ways of preventing internal threats aimed at achieving the basic economic goal. In particular, the main ways of preventing internal threats to the economic security of food industry enterprises in the Chernivtsi region are the following (Figure 6). 
DOI: 10.14807/ijmp.v11i9.1422

The main ways to prevent internal threats to the enterprises economic security of food industry in Chernivtsi region

To reduce the risk of the financial component, measures that are coordinated to ensure an adequate level of liquidity, increase the efficiency of the equity capital use through growth to a sufficient level of net income
To increasing the intensity of asset utilization, reducing the level of moral and physical deterioration of fixed assets, increasing resource efficiency and accelerating the funds turnover invested in assets
To develop the economic security of the personnel component and it will be ensured by reducing the share of retirement age employees, stimulating the labor activity of staff, reducing the turnover, attracting skilled labor.

Figure 6: The main ways to prevent internal threats to economic security of food industry enterprises

Source: by the authors

The implementation of the identified ways of preventing internal threats to the enterprise economic security requires appropriate measures. Means to implement ways to prevent internal threats will also vary within each individual component of the enterprise economic security.

Preventing internal threats to the technical and technological component in the context of fixed assets of food industry enterprises of Chernivtsi region becomes possible under the following conditions:

- release of the enterprise from unnecessary equipment, machines and other fixed assets or lease them;

- timely and high-quality carrying out of planned preventive and major repairs;

- acquisition of high quality fixed assets; professional development of service personnel;

- timely updating, especially of the active part, of fixed assets in order to prevent excessive moral and physical deterioration;

- improving the organization of work in order to reduce the working time loss.

Preventing internal threats of the technical and technological component in the context of working capital of the food industry enterprises in Chernivtsi region becomes possible under the following conditions:

- ensuring the optimal ratio between the required volume of working capital and their production need;

- economical and rational disposition of inventory;

- optimizing inventory costs; 
- ensuring the minimum flow of working capital in stocks while maintaining the continuity of the operating process;

- self-financing of working capital needs is maximum possible.

Among the main measures for the ways implementation to prevent internal threats to the financial component of the economic security of food industry enterprises in Chernivtsi region will be the main measures aimed at improving the efficiency of capital management, improvement of payment systems; increased investment in resource savings; the application of the principle in compliance with the critical credit terms; an information centre creation for accounts receivable and payable. The financial component of the economic security of the food industry enterprises in Chernivtsi region should be optimized by intensifying marketing activities, which foresees the markets diversification, strengthening the personnel component of economic security.

The formation of a positive image is directly influenced by such basic tools as marketing, design, psychology, advertising, PR-specialists, which as a result shape the image from the consumer' view, in the social sphere, in the public sphere, the internal image in the staff, and the image in the business society. In result, there is a social and economic effect.

The economic effect gives you the opportunity to receive higher brand rewards, the opportunity to expand the market share, i.e. increase the sales volume, and increase the brand value.

The main objective of ensuring the economic security of the studied enterprise is to guarantee its stable and maximum effective functioning and high potential for development in the future.

The analysis results in a program of action with strategic and tactical plans that specifies recommendations according to the identified problem areas of the enterprise. This program is based on the selected approaches to image management of the studied enterprise, which are further formed into an image project.

Thus, the fact of the influence image on ensuring its economic security is proved, in particular it is shown:

- mutual influence of the image and components of the enterprise economic security;

- mutual correspondence of levels of economic security components and components of the enterprise image; 
On this basis, a matrix of assessment and alignment of the image and economic security levels was built, which makes it possible to comprehensively analyse the image impact on the activity of the enterprise and harmonize their mutual influence, purposefully manage the image from the view of ensuring economic security.

The generating technologies of each component of the image in the tool context of the marketing mix have their own peculiarities and specificity and therefore they can be created in stages by the enterprise on the basis of its available resources (production, energy, finance, investment, human resources), analysis of factors of macro and microenvironment and identification of potential demand for enterprise products in the selected market segment or in the non-occupied niche competitors.

Having determined the level of each component and the indicators of its impact, it is necessary to understand the general situation in the enterprise and the influence image on ensuring its economic security (table 4). Based on the data, we propose to evaluate the correspondence of the image level and the economic security level with the help of a matrix (Table 5). Quadrants that intersect their enterprise specific values provide options for further actions.

The process of creating the image of food processing enterprises is connected with the process of its support. As the company image is constantly changing, the issues of changes constant monitoring in this category among contact audience groups become relevant.

At the core of the personality image of the head of the company creates the entire system shell of the image layers of his person. We offer to consider a block model of managing the image and reputation of the company, which distinguishes four blocks of parameters: regulatory, stabilizing, stimulating and evaluating (Table 6).

Table 4: The correspondence of the level of economic security components and image for the food industry enterprises

\begin{tabular}{|c|c|c|c|}
\hline $\begin{array}{c}\text { The economic } \\
\text { security } \\
\text { components }\end{array}$ & $\begin{array}{l}\text { The image } \\
\text { element }\end{array}$ & $\begin{array}{c}\text { The } \\
\text { level of } \\
\text { the } \\
\text { element }\end{array}$ & The image state \\
\hline \multirow[t]{4}{*}{ Financial } & \multirow[t]{4}{*}{$\begin{array}{l}\text { Business } \\
\text { image }\end{array}$} & $\begin{array}{l}\text { Very } \\
\text { low }\end{array}$ & Absence of well-established work with economic counterparties. \\
\hline & & Low & $\begin{array}{l}\text { Low level of business activity, instability of relations with economic } \\
\text { counterparts, wrong choice of pricing strategy. }\end{array}$ \\
\hline & & Average & $\begin{array}{l}\text { Established but unstable relationships with economic counterparts and other } \\
\text { contact audiences. }\end{array}$ \\
\hline & & High & $\begin{array}{l}\text { Large number of economic counterparties, presence of reliable partnerships, } \\
\text { high investment attractiveness of the enterprise. }\end{array}$ \\
\hline \multirow{2}{*}{$\begin{array}{l}\text { Intelligent } \\
\text { and } \\
\text { personnel }\end{array}$} & \multirow[t]{2}{*}{$\begin{array}{l}\text { Internal } \\
\text { image }\end{array}$} & $\begin{array}{l}\text { Very } \\
\text { low }\end{array}$ & Lack of highly qualified staff, the manager's incompetence. \\
\hline & & Low & $\begin{array}{l}\text { Low level of the staff and manager professionalism; low motivation, unformed } \\
\text { organizational culture. }\end{array}$ \\
\hline
\end{tabular}


ISSN: 2236-269X

DOI: 10.14807/ijmp.v11i9.1422

\begin{tabular}{|c|c|c|c|}
\hline & & Average & $\begin{array}{l}\text { Insufficient level of the staff professionalism and low level of work motivation, } \\
\text { underdeveloped organizational culture. }\end{array}$ \\
\hline & & High & $\begin{array}{l}\text { Highly qualified staff, high level of employees' motivation and developed } \\
\text { organizational culture. }\end{array}$ \\
\hline \multirow[t]{4}{*}{ Technological } & \multirow{4}{*}{$\begin{array}{l}\text { Personnel } \\
\text { image, } \\
\text { product } \\
\text { image }\end{array}$} & $\begin{array}{l}\text { Very } \\
\text { low }\end{array}$ & $\begin{array}{l}\text { Discrepancy in the quality of goods to consumer demand, due to the very low } \\
\text { level of production technology and professionalism of staff. }\end{array}$ \\
\hline & & Low & $\begin{array}{l}\text { Low level of the staff and manager professionalism, low level of innovation, } \\
\text { technological quality of production and progressiveness of production } \\
\text { technologies. }\end{array}$ \\
\hline & & Average & $\begin{array}{l}\text { Lack of qualified personnel, low level of innovation and the products technical } \\
\text { mastery. }\end{array}$ \\
\hline & & High & Use of high-tech equipment for production of high-quality innovative products. \\
\hline \multirow[t]{4}{*}{ Legal } & \multirow{4}{*}{$\begin{array}{c}\text { Business } \\
\text { image, } \\
\text { organizational } \\
\text { culture and } \\
\text { SPK }\end{array}$} & $\begin{array}{l}\text { Very } \\
\text { low }\end{array}$ & $\begin{array}{l}\text { A large number of complaints about the company law-abiding nature, which is } \\
\text { manifested in the work with business partners and staff. }\end{array}$ \\
\hline & & Low & $\begin{array}{l}\text { Unstable and weak work with economic counterparties and government } \\
\text { agencies, failure to comply with the terms of business agreements, etc. }\end{array}$ \\
\hline & & Average & $\begin{array}{l}\text { Some problems with economic counterparties cooperation, government } \\
\text { institutions, or staff. }\end{array}$ \\
\hline & & High & High internal image and business activity. \\
\hline \multirow[t]{4}{*}{ Market } & \multirow{4}{*}{$\begin{array}{l}\text { Business } \\
\text { image, image } \\
\text { of the head }\end{array}$} & $\begin{array}{l}\text { Very } \\
\text { low }\end{array}$ & $\begin{array}{l}\text { Unspecified specific positioning of the company on the market, unbalanced } \\
\text { contacts with contact groups and economic counterparties. }\end{array}$ \\
\hline & & Low & $\begin{array}{l}\text { Low level of staff and manager professionalism, dissatisfaction with customer } \\
\text { requests. }\end{array}$ \\
\hline & & Average & $\begin{array}{l}\text { The need to increase the professionalism of the staff, creative and non-standard } \\
\text { approach to solving marketing problems. }\end{array}$ \\
\hline & & High & Manager and staff high image. \\
\hline \multirow[t]{4}{*}{ Interface } & \multirow{4}{*}{$\begin{array}{l}\text { Business } \\
\text { image, visual } \\
\text { image }\end{array}$} & $\begin{array}{l}\text { Very } \\
\text { low }\end{array}$ & $\begin{array}{l}\text { Lack of information about the requests and expectations of contact groups and } \\
\text { economic counterparties from cooperation with the enterprise. }\end{array}$ \\
\hline & & Low & $\begin{array}{l}\text { Low consumer loyalty, unstable financial position, unreliable economic } \\
\text { counterparties, default, low potential. }\end{array}$ \\
\hline & & Average & $\begin{array}{l}\text { Unstable communications with economic counterparties, little industry } \\
\text { experience. }\end{array}$ \\
\hline & & High & Relationship with all contact engagement groups. \\
\hline \multirow[t]{4}{*}{ Ecological } & \multirow{4}{*}{$\begin{array}{l}\text { Social } \\
\text { andecological } \\
\text { image }\end{array}$} & $\begin{array}{l}\text { Very } \\
\text { low }\end{array}$ & $\begin{array}{l}\text { Failure to meet production quality standards, use of prohibited substances in } \\
\text { production, non-compliance with safety rules, etc. }\end{array}$ \\
\hline & & Low & Failure to comply with environmental standards, reduce competitiveness. \\
\hline & & Average & $\begin{array}{l}\text { The need to increase the level of the production process greening, the } \\
\text { introduction of social and environmental measures. }\end{array}$ \\
\hline & & High & High level of social and ecological image. \\
\hline \multirow[t]{3}{*}{ Informational } & \multirow[t]{3}{*}{$\begin{array}{l}\text { Internal } \\
\text { image }\end{array}$} & $\begin{array}{l}\text { Very } \\
\text { low }\end{array}$ & Lack of information about the enterprise activity. \\
\hline & & Low & $\begin{array}{l}\text { Lack of information in the media about the activity of the enterprise or its } \\
\text { unreliability, low level of internal image, low information openness of the } \\
\text { enterprise. }\end{array}$ \\
\hline & & Average & $\begin{array}{l}\text { Incomplete awareness of all contact liaison groups about the company and its } \\
\text { activities. }\end{array}$ \\
\hline
\end{tabular}

Source: by the authors

Table 5: The matrix of assessment and alignment of the image and economic security levels for the food industry enterprises

\begin{tabular}{|c|c|c|c|c|}
\hline \multirow{2}{*}{$\begin{array}{l}\text { The image } \\
\text { level }\end{array}$} & \multicolumn{4}{|c|}{ The economic security level } \\
\hline & High & Average & Low & Very low \\
\hline High & $\begin{array}{l}\text { Saving the competitive } \\
\text { advantage }\end{array}$ & \multicolumn{3}{|c|}{$\begin{array}{l}\text { Transferring the benefits of high image to } \\
\text { the economic security components }\end{array}$} \\
\hline Average & \multicolumn{2}{|c|}{$\begin{array}{l}\text { Improvement of image indicators to the economic } \\
\text { security components }\end{array}$} & \multicolumn{2}{|c|}{$\begin{array}{l}\text { Transferring the benefits of medium } \\
\text { image to the economic security } \\
\text { components }\end{array}$} \\
\hline Low & \multirow{2}{*}{\multicolumn{2}{|c|}{$\begin{array}{l}\text { Increasing the level of image through the economic } \\
\text { security index, which influence the formation of a } \\
\text { positive image }\end{array}$}} & \multirow{2}{*}{\multicolumn{2}{|c|}{$\begin{array}{l}\text { Increasing the level of economic } \\
\text { security and image }\end{array}$}} \\
\hline Very low & & & & \\
\hline
\end{tabular}

Source: by the authors 
Table 6: Main blocks of image management of the food industry Enterprises

\begin{tabular}{|l|l|}
\hline $\begin{array}{c}\text { Blocks of parameters control of the enterprise } \\
\text { image and reputation technologies }\end{array}$ & \multicolumn{1}{|c|}{ The main mission of the blocks } \\
\hline $\begin{array}{l}\text { Regulatory involves marketing tools: price; logistic; } \\
\text { communicative; informational }\end{array}$ & $\begin{array}{l}\text { Generating, self-presenting, regulating, creating and } \\
\text { positioning all the major components of an } \\
\text { enterprise image; regulation of the ratio and } \\
\text { interaction of its main components }\end{array}$ \\
\hline $\begin{array}{l}\text { Stabilizing has social and psychological tools: } \\
\text { perceptual, cognitive, informational and } \\
\text { communicative }\end{array}$ & $\begin{array}{l}\text { Supportive, corrective: maintaining and adjusting } \\
\text { the balance of all major components of the image } \\
\text { and reputation of the enterprise }\end{array}$ \\
\hline $\begin{array}{l}\text { Promoting consists of stimulating tools: sponsorship } \\
\text { development, social projects development, } \\
\text { introduction of innovative image elements, } \\
\text { application of innovative image elements }\end{array}$ & $\begin{array}{l}\text { Stimulating, innovative: promoting positive } \\
\text { motivational and behavioral activity of consumers } \\
\text { towards the enterprise, developing and improving } \\
\text { the image and reputation of the enterprise }\end{array}$ \\
\hline $\begin{array}{l}\text { Assessment includes valuation tools: creation and } \\
\text { development of models for evaluating the } \\
\text { components of the image, as well as the overall } \\
\text { image and reputation of the enterprise }\end{array}$ & $\begin{array}{l}\text { Measuring, evaluating: measuring and evaluating } \\
\text { an enterprise image and reputation based on } \\
\text { feedback from a corporate audience }\end{array}$ \\
\hline
\end{tabular}

Source: by the authors

It is necessary to follow a certain sequence of actions aimed at maintaining the company image, which will be convenient to use as a separate unit (Figure 7).

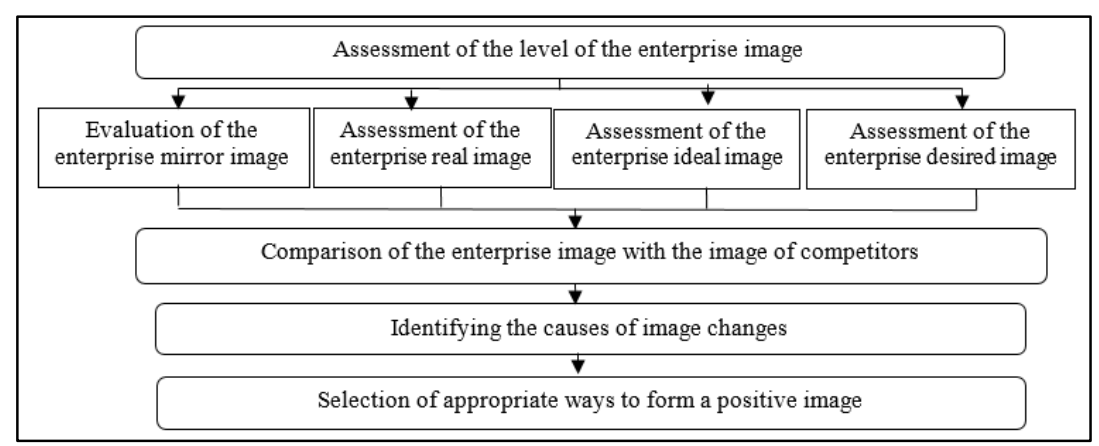

Figure 7: The positive image stages for the support of the food industry enterprises Source: by the authors

It should be kept in mind that each group of these parameters should be implemented in a modern marketing system, taking into account the specificity of the integrated marketing mix. The role of this image model is that it can be used in the calculation of the food industry costs for the formation of the image for each of the selected components.

\section{CONCLUSIONS AND RECOMMENDATIONS}

The proposed, the fact of the image influence on ensuring its economic security was established, in particular: the mutual influence of the image and the components of the economic security of the enterprise; the mutual correspondence of the levels of the economic security components and components of the enterprise image. 
On this basis, a matrix of assessment and alignment of the levels image and economic security was built, which makes it possible to comprehensively analyse the impact of the image on the activity of the enterprise and harmonize their mutual influence, purposefully manage the image from the view of ensuring the economic security.

In the context of this tool, based on the management strategy developed by the company, a basic model of the image is formed, which can be represented as a balanced volume quadrangle, the parties of which are the main components of the image related to the formation of the product image, the price image, the distribution image, the promotion image (Figure 8).

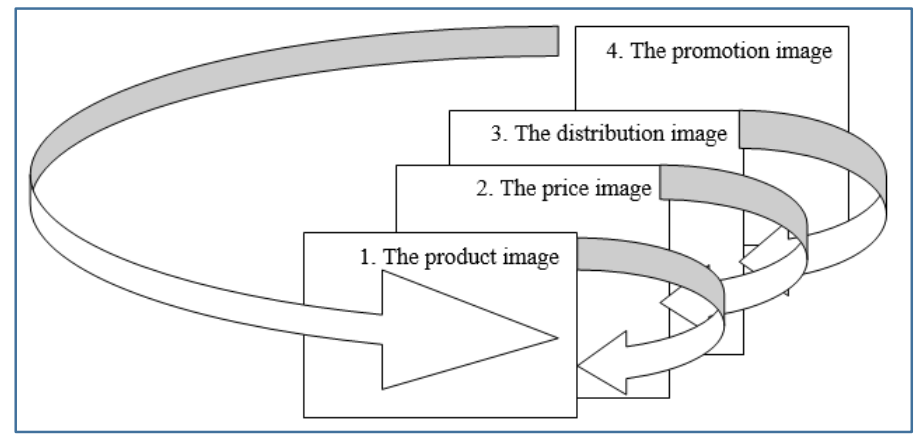

Figure 8: Image model in the context of the marketing mix of food industry enterprises Source: by the authors

The obtained results management of the economic security systems of food industry enterprises should include the following objectives (Figure 9).

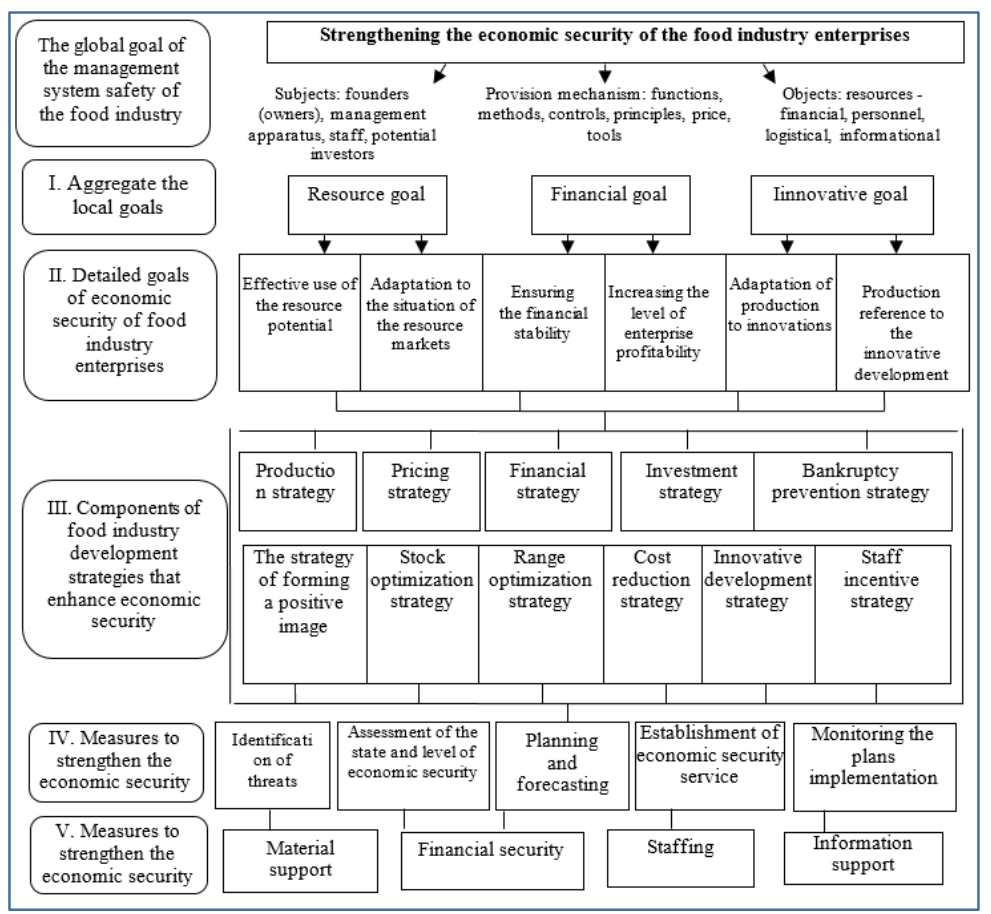

Figure 9: Components of the economic security management system of food industry enterprises

Source: by the authors 
DOI: 10.14807/ijmp.v11i9.1422

So, the model of process of image support of the investigated enterprises in food industry is offered, which consists of four stages: estimation of the level of the enterprise image; comparing the level of the enterprise image with the image of competitors; determining the reasons for changes in the enterprise image; the appropriate tools selection to support the image of food businesses.

The purpose and the main indicator of the efficiency in functioning of the formation mechanism of the enterprises economic security is the profit. If the enterprise in result of the reporting period receives losses, it does not receive profit, or its size does not correspond to the amount of invested funds, it can be argued that the mechanism of economic security formation is not effective.

The economic security formation of food industry enterprises is a long and costly process that requires restructuring of both the management system and production, economic, investment, financial, marketing, and marketing activities. The problem of analysis, evaluation and diagnostics of the level of the enterprise economic security is solved, as it is fair to assume that the processes that are fulfilled at the enterprise and its results of activity reflect the development of the whole population.

The proposed system of economic security management defines goals, outlines the main strategies and aims at achieving the main goal of managing the economic security of the food industry.

The system of economic safety management of the food industry enterprises is offered, it will help to increase the social and economic responsibility of the enterprises in the studied industry and strengthen their new position in the market.

\section{REFERENCES}

ANISHCHENKO, I.; PINCHUK, Yu. (2005) Assessment of the Effectiveness and finance support of small business development programs in the region. Ekonomika ta derzhava, $\mathrm{n}$. 10, p. 29-33. (in Ukranian)

AREFIEVA, O. V.; KUZENKO, T. B. (2004) Planuvannia ekonomichnoi bezpeky pidpryiemstv: monohrafiia [Planning of enterprises economic security: monograph]. Kyiv: Publishing house of European university. (in Ukranian)

BAZHENOVA, O. (2018) Methods of determining the assessment of economic security of the state. Actual problems of business development in Ukraine, v. 3, p. 4-9. (in Ukranian)

CHYKURKOVA, A. (2016) Strategy of small business in Khmelnytsky Region. The Economic Discourse, n. 4, p. 74-81. Available:

<http://ed.pdatu.edu.ua/article/view/124443〉. Access: 19 May 2020. (in Ukranian) 
DONECZ, L.; et al. (2008) Economic security of the company. Kyiv: Tsentr uchbovoi literatury. (in Ukranian)

FEN, K. (2018) System of management of economic safety of food industry enterprises.

Formation of market relations in Ukraine, v. 4, p. 115-119. Available:

<http://nbuv.gov.ua/UJRN/frvu_2018_4_20>. Access: 21 May 2020. (in Ukranian)

FRANCHUK, V. (2009) Corporate relations in the security system of joint stock companies. Current problems of the economy, v. 1, p. 145-150. (in Ukranian)

GORYACHEVA, K. (2003) Financial security of the enterprise, essence and place in the economic security system. Economist, v. 8, p. 65-67. (in Ukranian)

HAUSHOFER, K. (2001) About geopolitics. Work of different years. Moscow: Musli. (in Russian)

IHNASHKINA, T.; SHATOKHIN, A. (2019) The essence and components of the mechanism of economic security management of the enterprise. Business Inform, v. 1, n. 19, p. 139-143. DOI: https://doi.org/10.26661/2414-0287-2019-1-41-24.

ILIENKO, O. (2013) Development of the theory of "economic security of enterprise" in the countries with transformation economy. Formation of market relations in Ukraine, v. 1, p. 91-97. (in Ukranian)

KOZACHENKO, G. V.; PONOMARYOV, V. P.; LYASHENKO, O. M. (2007) Economic security of an enterprise: the essence and providing mechanism: monograph. Kyiv: Libra. (in Ukranian)

MARTYUSHEVA, L.; KUZENKO T.B.; LYTOVCHENKO O.Iu. (2008) Financial security of the enterprise. Kharkiv: Vyd-vo KhNEU. (in Ukranian)

MASLAK, O.; HRISHKO, N. (2013) The economic security management of enterprise according to the principles of its rational level provision. Marketing and innovation management, $n$. 1. Available: <http://nbuv.gov.ua/UJRN/Mimi_2013_1_20>. Access: 19 May 2020. (in Ukranian)

MISHCHENKO, S. (2012) Conceptual Aspects of Economic Security of Enterprises in a Market Economy Contseptual aspects of economical safety of enterprises in market economics. Marketing and innovation management, v. 37, p. 215-220. Available: $<$ https://cyberleninka.ru/article/n/kontseptualni-osnovi-zabezpechennya-ekonomichnoyibezpeki-pidpriemstva>. Access: 11 June 2020.

MOJSEYENKO, I.; MARCHENKO, O. (2011) Management of financial and economic security of the enterprise. Naukovyi visnyk NLTU, v. 21, n.. 2, p. 141-146. (in Ukranian)

ORLYK, O. V. (2015) The Mechanism of Financial and Economic Security Management of an enerprise and its Main Components. Financial and credit activity: problems of theory and practice, [S.1.], v. 2, n. 19, p. 222-232. DOI:

http://dx.doi.org/10.18371/fcaptp.v2i19.57391.

POLYARUSH, A.; YURCHENKO, A. (2011) Information war against Ukraine: causes and socio-political technologies. Kyiv: KYJ. (in Ukranian)

PONOMAREV, V. (1998) Economic security of the enterprise: the nature and criteria of evaluation. Visnyk Skhidnoukrainskoho derzhavnoho universytetu, v. 3, p. 90-96. (in Ukranian)

PYRUMOV, V. (1993) Some aspects of the methodological study of the problem of national security of in modern conditions. Heopolytyka y bezopasnost, v. 1, p. 7-17. (in Russian) 
SAATI, T. (1993) Decision making. The method of hierarchy analysis. Moscow: Radio and connect. (in Russian)

SIVOLAP, L. (2014) Enterprise security service as a factor in its economic security.

Theoretical and practical aspects of economics and intellectual property, v. 1, n. 10, p. 121-125. (in Ukranian)

VASYLTSIV, T. (2008) Economic security of Ukrainian enterprise: strategy and mechanism of strengthening. Lviv: «Aral». (in Ukranian) 